\title{
South African Spider Diversity: African Perspectives on the Conservation of a Mega-Diverse Group
}

\author{
Stefan H. Foord ${ }^{1}$, Anna S. Dippenaar-Schoeman ${ }^{2,3}$ and Charles R. Haddad ${ }^{4}$ \\ ${ }^{1}$ Department of Zoology, University of Venda \\ ${ }^{2}$ ARC-Plant Protection Research Institute, Queenswood \\ ${ }^{3}$ Department of Zoology and Entomology, University of Pretoria \\ ${ }^{4}$ Department of Zoology \& Entomology, University of the Free State \\ South Africa
}

\section{Introduction}

Any field of endeavour requires retrospection after a period of substantial activity. This process provides a measure of what has been achieved and identifies future directions. Studies of spider diversity in South Africa have gone through an intense growth phase over the past ten years and reached a stage in its development where reflections on patterns and processes observed could provide meaningful input into the identification of further work. This chapter establishes the background and framework for such a discussion on the path to a more holistic conservation planning that includes invertebrates.

Invertebrate conservation and diversity pose a significant challenge to planners and managers (Engelbrecht, 2010), and in spite of the central role that insects and arachnids play in terrestrial biodiversity, they still remain peripheral to decision-making processes. The reality is that, for Africa in particular, there are very few conservation areas that have both the resources and expertise to include invertebrates as part of their monitoring and management initiatives (however, see South African River Health Programme ${ }^{1}$ ).

The advent of adaptive management, with a strong emphasis on experimental implementation of alternative management options (Johnson, 1999), has informed much of recent thinking and has cast a dim light on classical inventory studies that generate species lists. However, records of the numbers of species and their distribution provides a fundamental starting point for the conservation of biodiversity (Pullin, 2002). This view also ignores the contribution that basic inventories and alpha taxonomy make to the initial development of a field.

This chapter will show that South African spider systematics and ecology are in an exploratory phase, and that traditional approaches to mapping diversity has enabled spider ecology in the country to generate species lists that are often resolved up to species level. Very few other studies on mega-diverse invertebrate groups in Africa can match this taxonomic resolution (see e.g. Formicinae). This descriptive phase will provide the

\footnotetext{
${ }^{1}$ www.dwa.gov.za/iwqs/rhp
} 
foundations for more integrative work in future, and any attempts to ignore the importance of providing baseline biodiversity and taxonomic data will hamper subsequent attempts to develop a deeper understanding and appreciation of this unique heritage.

The real significance of this heritage is highlighted by recent work throughout Africa that point to the global relevance of Southern African spider diversity (Jocqué, pers. com.). Contrary to the general trend of decreasing diversity at higher latitudes (Jenkins et al. 2011), spider richness increases towards the middle and southern latitudes of Africa, i.e. a humpshaped distribution, peaking in Southern Africa (Platnick, 1991). This region is also characterized by ancient landscapes that have remained relatively stable for millions of years, with several relictual taxa that were once more widely distributed (Jocqué, 2008).

As signatories to the Convention on Biodiversity2 ${ }^{2}$ South Africa is obliged to develop a strategic plan for the conservation and sustainable utilization of this heritage. The convention also has two key objectives, which are the "identification and monitoring" of biological diversity and "public education and awareness" (articles 7 and 13). The South African National Survey of Arachnida (SANSA) was initiated to address this by discovering, describing and inventorying the South African arachnid fauna (Dippenaar-Schoeman \& Craemer, 2000). In addition to this, the project also had a strong element of public involvement.

The second phase of SANSA that was initiated in 2006 saw the integration of a series of ad hoc projects into targeted surveys in degree squares throughout South Africa (DippenaarSchoeman, 2007). Annual accessions of specimens in the South African National Collection of Arachnida (Pretoria) increased three-fold from the start of this second phase (Fig. 1).

Despite the extensive sampling carried out during this phase, several gaps and areas in South Africa that are underrepresented in the database still remain (Fig. 2). This can largely be attributed to logistical challenges, restricted manpower and time necessary to sample these areas properly, particularly in the western parts of South Africa. However, there are certain patterns that are evident, several lessons were also learnt, and we detail these based on the ca. 50000 records accessioned as part of SANSA. This chapter also provides a general overview of spider biodiversity at the biome scale and a vision of future directions of spider diversity studies in South Africa.

\section{Information needs of a developing country}

Based on current estimates there are a total of 2010 species in 70 families recorded from South Africa. This represents $61 \%$ of the world's family fauna. Of these species, 1220 (> 60\%) are endemic to the region, including two families, Chummidae (Jocqué, 2001) and Penestomidae (Miller et al., 2010). This high level of endemicity could partly result from the low inventory levels beyond South Africa's borders.

As our database is plagued by undersampling, we provide estimates of spider diversity in some of the studies, and although species richness is a crude measure of diversity, it could provide some indication of inequalities between areas and their significance to conservation. A summary table of spider species richness found in each of the biomes suggest that the Savanna Biome is the most diverse but sampling is very uneven (Table 1). Limited sampling in the Fynbos Biome precludes any definitive statements, but it is evident that Fynbos

\footnotetext{
${ }^{2}$ www.cbd.int
} 


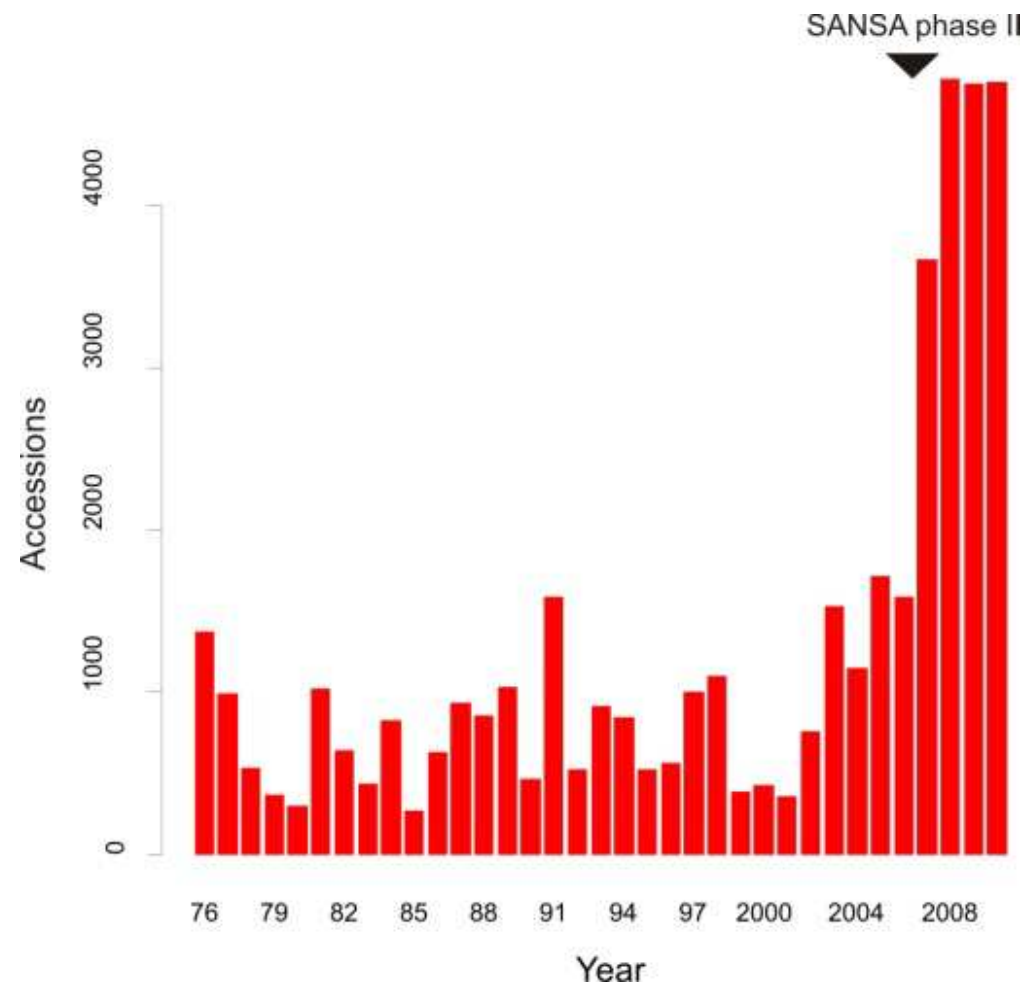

Fig. 1. Spider accessions per year in the South African National Collection of Arachnida, the largest in Africa.

Biomes

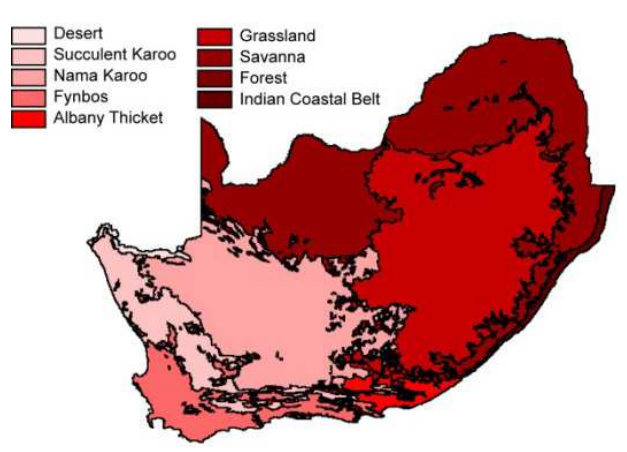

No. of Records

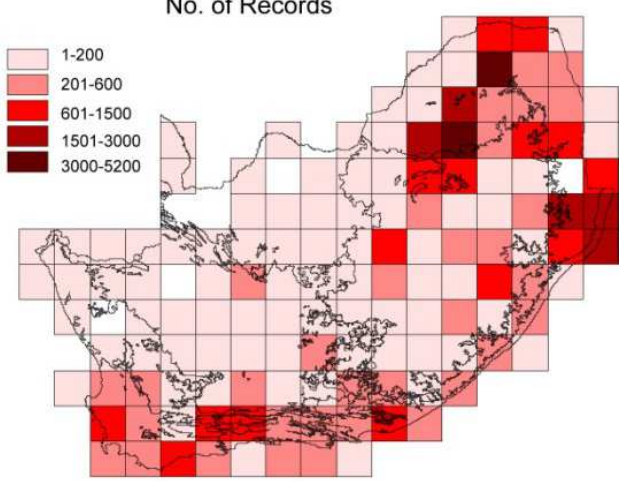

Fig. 2. Biomes of South Africa (Mucina \& Rutherford, 2006) and the number of spider records for each degree square throughout South Africa. 
diversity matches that of degree squares in savanna subjected to the same sampling intensity (Fig. 3). The Grassland Biome seems to be the next most diverse biome, followed by forests. In contrast, Thicket, Nama Karoo and Succulent Karoo have not been sampled sufficiently to suggest any pattern.

\begin{tabular}{|c|c|c|}
\hline Biome & No. of sites & No. species \\
\hline Savanna & 46 & 1201 \\
\hline Grassland & 27 & 655 \\
\hline Forest & 5 & 508 \\
\hline Fynbos & 13 & 636 \\
\hline Nama Karoo & 8 & 464 \\
\hline Succulent karoo & 1 & 219 \\
\hline Thicket & 3 & 464 \\
\hline
\end{tabular}

Table 1. Number of sites for each biome that have more than 100 accessions, together with total number of species recorded for each biome.

\subsection{The Savanna, largest and most diverse biome, issues of scale and heterogeneity} Savanna ecosystems cover approximately $60 \%$ of the land surface of sub-Saharan Africa. The biome is recognized by a discontinuous overstory of woody plants and a herbaceous layer dominated by grasses. Rainy seasons are short with long dry seasons and the temperature is warm almost all year round. Rainfall is relatively high $(500-2000 \mathrm{~mm})$ but usually concentrated over short periods of time. Currently there are $1201 \mathrm{spp}$. $(60 \%$ of the South African fauna) in 370 genera and 61 families known from this biome in South Africa. Of the 1201 spp., 327 spp. are endemic to the savanna and 322 are near endemics. Salticidae is the most diverse family (157 species) followed by Thomisidae (116) and Gnaphosidae (106). Characteristic taxa include species of the genus Hersilia, particularly those within the Hersilia sericea species-group (Foord \& Dippenaar-Schoeman, 2006), orb-weavers such as Araneus apricus, Cyclosa insulana and Isoxya tabulata, and crab spiders, viz. Diaea puncta, Thomisops scrupeus, Simorcus cotti and Runcinia flavida. All these species are foliage dwellers, and the absence of diagnostic ground dwelling species are probably the result of the localised distribution of epigeal species within the Savanna Biome.

A total of 10 published surveys of the Savanna Biome have been undertaken over the last 20 years (Dippenaar-Schoeman et al., 1989; Foord et al., 2002; Whitmore et al., 2002; DippenaarSchoeman \& Leroy, 2003; Modiba et al., 2005; Haddad et al., 2006; Dippenaar et al., 2008; Foord et al., 2008; Dippenaar-Schoeman et al., 2009; Muelelwa et al., 2010). The savanna has been better sampled than the other biomes and predictably has the most records (Fig. 2). Unfortunately, even this biome still suffers from severe undersampling, and species richness is largely a function of sampling effort, although it does seem to asymptote at approximately 350 species per degree square (Fig. 3). Some of the degree squares in this biome are the most diverse in South Africa, e.g. the degree squares that contain Ndumo Game Reserve in northern KwaZulu-Natal and the Western Soutpansberg in Limpopo Province.

Undersampling is, however, the rule rather than the exception, even in sites that have been intensively sampled (Coddington et al., 2009). For example, after 150 one-person hours worth of effort and 100 pitfalls left open for 20 days in 16 ha of a savanna vegetation type in 
the Limpopo Province, Muelelwa et al. (2010) sampled less than $50 \%$ of the species present. Their data was fitted to a lognormal distribution and species richness estimates varied between 370 and 450 for the two 16 ha sites sampled (Muelelwa et al., 2010). With the default hypothesis of undersampling, the 431 species recorded from Ndumo Game Reserve (Haddad et al., 2006; Wesołowska \& Haddad, 2009) is exceptional. Subsequent collecting in this reserve by canopy fogging, pitfall trapping and hand collecting has expanded our knowledge of the fauna, which now exceeds 500 species.

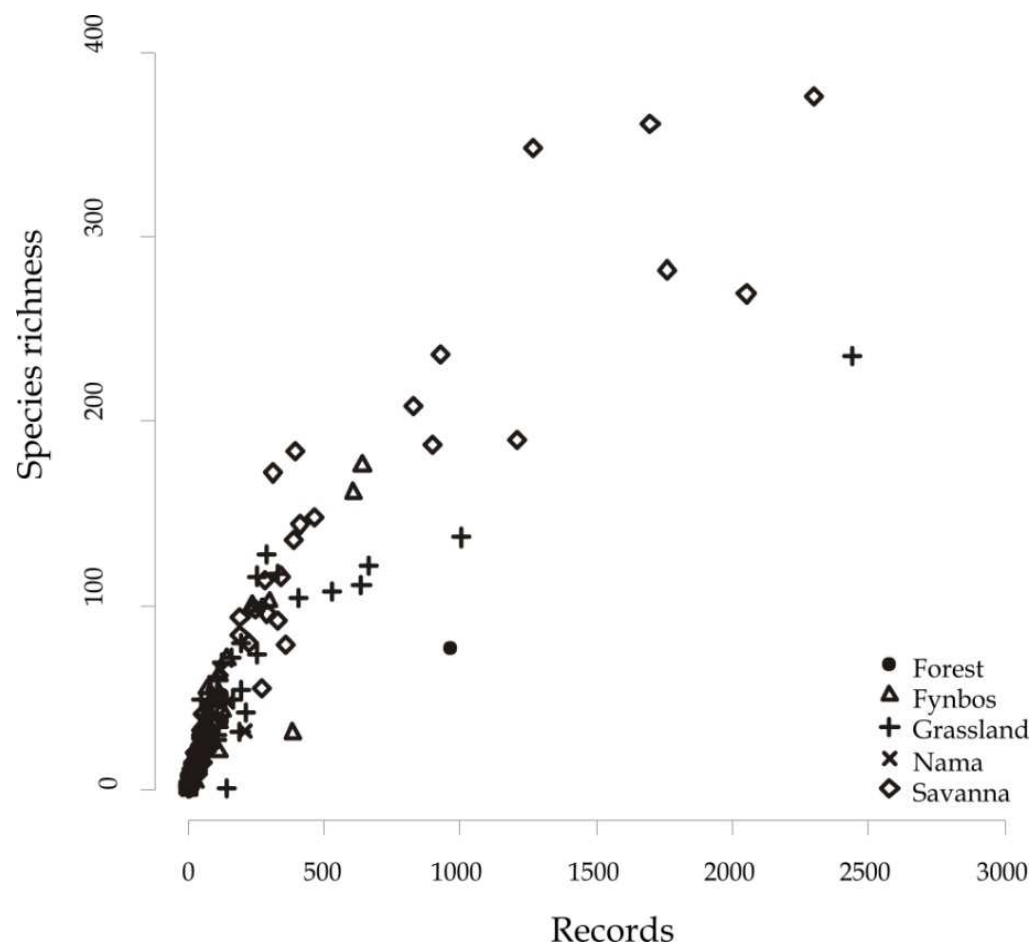

Fig. 3. Number of species vs. the number of sampling records in each of the 143 degree squares categorized according to biomes in South Africa, Succulent Karoo and the Thicket Biomes were excluded due to insufficient sampling.

Savannas are one of the most heterogeneous ecosystems, both spatially and temporally, in the world (Lomolino et al., 2006). Therefore, in addition to alpha diversity at a site, understanding the role of beta diversity and the scale at which assemblages respond to the environment are particularly important considerations for managing a particular taxon's diversity in this biome. The results from three concurrent semi-quantitative studies between May 2004 and March 2006 in Limpopo Province (Dippenaar et al., 2008; Foord et al., 2008; Muelelwa et al., 2010) provides a basis for evaluating the role of alpha vs. beta diversity in generating spider diversity at various scales. The degree of turnover between the spider assemblages of the 18 plant communities distributed over 4 sites was summarized by computing Bray-Curtis similarities and the Chao estimator of the Sørensen similarity index (Chao et al., 2005); the latter index includes the effect of undetected species. 
The results from these three surveys, viz. Dippenaar et al. (2008), Foord et al. (2008) and Muelelwa et al. (2010), yielded a total of 642 species. The regional richness of these four sites is comparable to the national check list of Portugal, with 757 species (Cardoso et al., 2008).
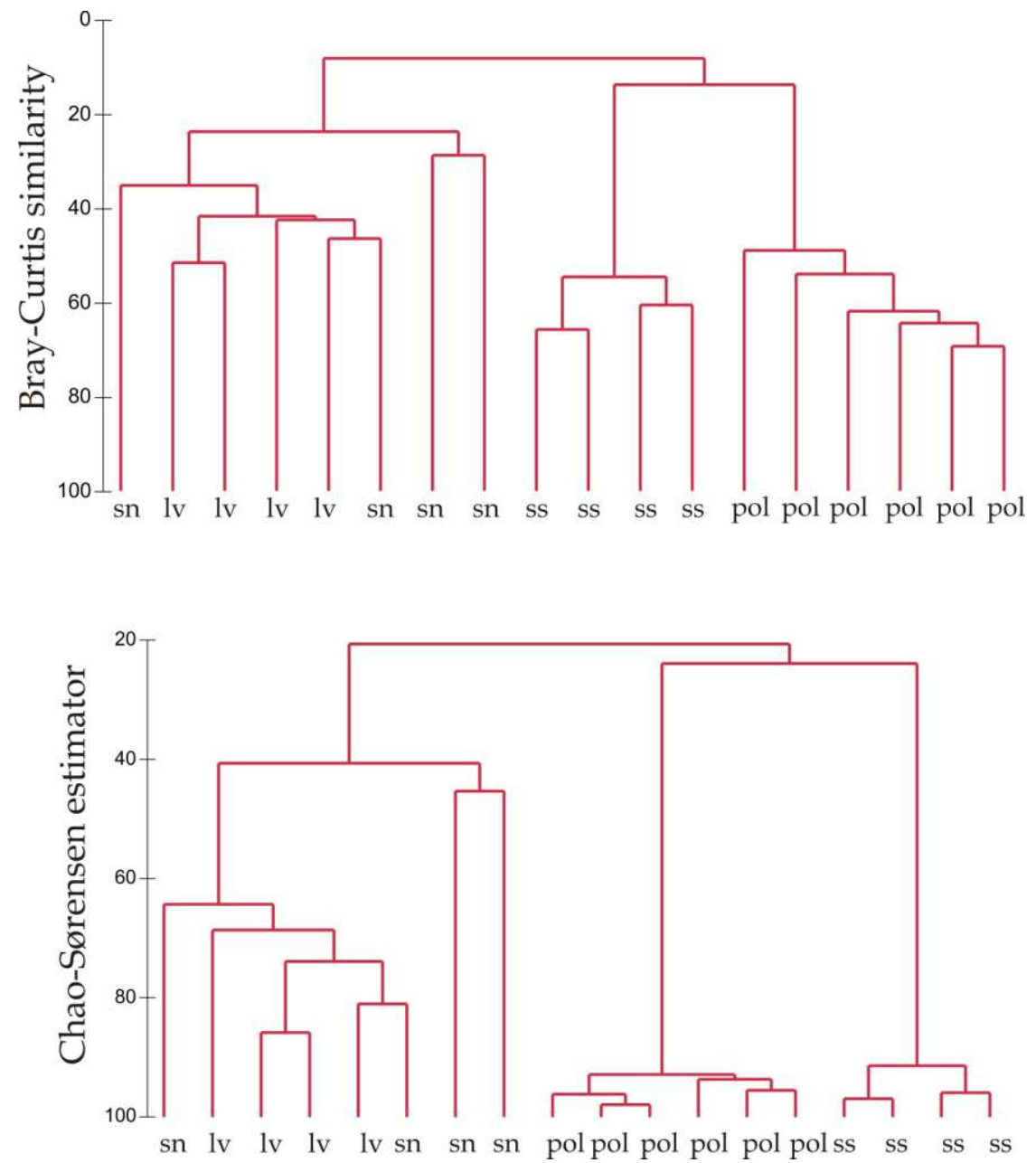

Fig. 4. Cluster diagrams of Bray-Curtis similarities and Chao-Sørensen estimators for the spider assemblages of the Limpopo valley (lv), Soutpansberg northern aspect (sn), Soutpansberg southern aspect (ss) and Polokwane Nature Reserve (pol) for semiquantitative surveys conducted between May 2004 and March 2006.

The Chao estimator of the Sorensen index suggests that turnover between plant communities in a site is very low, particularly for the southern aspect of the Soutpansberg and Polokwane, with estimated similarities exceeding 90 for plots within these sites. Turnover between the three surveys was very high, with similarities as low as 20 and never higher than 30 (Fig. 4). Even though the plant communities within each of these three sites 
differed substantially in structure, e.g. the grassland vs. woodland, estimates of similarities suggest that their spider assemblages are very similar within a site. As expected, estimates of similarities between plant communities within the three surveys increased with the amount of time spent surveying, e.g. Polokwane Nature Reserve had the highest similarity estimates (>90) and sampling was done over a twelve month period, followed by the southern aspect of the Soutpansberg (three months), and then the Limpopo valley and Soutpansberg northern aspect (two weeks). Limited turnover between plant communities might result if identifications are not consistent between surveys, particularly when morphospecies comprise $>30 \%$ of the spiders collected. However, two of the authors (Dippenaar-Schoeman and Haddad) were responsible for species as well as morphospecies determinations in all three studies, resulting in fully reconciled species lists.

The conservation implication of these patterns is that several small reserves that are geographically widely separated would maximize the spider diversity conserved, as long as a diversity of habitats with varied structure is maintained within each of these. This largescale regional comparison will have to be complimented with studies at more intermediate scales to establish the scale at which beta-diversity is generated. Studies in the next biome, grasslands, touch on the role of this turnover at smaller scales in generating spider diversity.

\subsection{Grasslands - Discovering new biotopes and species}

The Grassland Biome is found on the high central plateau of South Africa, including large parts of Gauteng, Mpumalanga, Free State, parts of North West, and the inland regions of KwaZulu-Natal and the Eastern Cape (Fig. 2). This biome is dominated by a single layer of grass and absence of trees, except in a few localised areas. There are many unique grassdwelling spiders found on the vegetation, with special adaptations in body form, colour, and web and retreat construction. A total of 57 families represented by 299 genera and 655 species have so far been recorded from this biome; $70 \mathrm{spp}$. are endemic to the biome and 156 are near endemic. The Salticidae with 77 species, followed by the Gnaphosidae (75) and Thomisidae (64) are the most species rich families. Grassland survey results have focused on the Free State (Lotz et al., 1991; Haddad \& Dippenaar-Schoeman, 2002, 2006a; Butler \& Haddad, In press), Gauteng (Van den Berg \& Dippenaar-Schoeman, 1991a), Mpumalanga (Makaka et al., In review) and KwaZulu-Natal provinces (Van der Merwe \& DippenaarSchoeman, 1996).

The species richness in degree squares found in the Grassland Biome diverges from that of the Savanna Biome, and the most diverse degree square has considerably fewer species than the most diverse degree squares in the savanna (Fig. 3). Even the outlier of the grassland is probably not a true reflection of real grassland diversity as it incorporates the city of Pretoria that occurs on the edge of the Savanna Biome.

Sampling in the majority of long- and short-term studies, as well as ad hoc collecting, relies heavily on the use of general techniques for collecting spiders, including pitfall trapping, sweep-netting and beating foliage. While these methods are efficient for collecting large numbers and estimating species richness of spiders, they say little about the microhabitat preferences of spiders. In the case of pitfall traps in grasslands, for example, the majority of species collected can be regarded as "typical" ground-dwelling species, regularly sampled at many sites within the Grassland Biome, while singleton and doubleton species are often represented by grass- and foliage-dwelling species that have fallen into pitfalls accidentally. As a result of these biases, supplementary methods such as hand collecting can often provide considerable information on individual species' microhabitat preferences, especially 
when microhabitat structural differences can be identified and considered. For example, hand collecting at the base of grass tussocks of different grass genera (e.g. Themeda, Eragrostis and Cymbopogon) and litter sifting under contrasting trees (e.g. Olea, Searsia and Cussonia) within the same habitat in central South Africa often yield very different faunas (Butler \& Haddad, In press, Haddad pers. obs.). To illustrate this point, three examples will be presented here.

The recently described tracheline sac spider Poachelas striatus Haddad \& Lyle, 2008 was initially reported from three localities in central Free State grasslands with a range of approximately $100 \mathrm{~km}$. All of the material had been sampled in the two years prior to its description, with most of the specimens collected at the base of grass tussocks, where this species is often very common (Haddad \& Lyle, 2008). This apparent restricted distribution was the result of two scenarios, i.e. distinct endemism in central South African grassland, or undersampling. To assess the distribution of the species in the Grassland Biome and beyond, several sites in the Free State, Northern Cape and Eastern Cape were sampled, with up to two hours of active searching at the base of grass tussocks carried out at each site. At all of the sites sampled P. striatus was collected, extending its range to approximately $900 \mathrm{~km}$ and its occurrence to the Savanna and Nama Karoo Biomes (Haddad, 2010).

The purse-web spider genus Calommata (Atypidae) was recently revised by Fourie et al. (2011), with two South African species recognized, namely C. transvaalica Hewitt, 1916 and C. meridionalis Fourie, Haddad \& Jocqué, 2011, known from savanna and grassland habitats, respectively. The initial discovery of $C$. meridionalis in the Erfenis Dam Nature Reserve in the Free State provided the first records of the genus from the Grassland Biome in South Africa. To assess its distribution, pitfalls were set out at six localities in the Free State. The species was only collected at two of these, where the soil structure could be considered as dark vertic clay or loamy-clay soils, which are usually associated with lower-lying areas near water bodies (Fourie et al., 2011). This was consistent with the soil types at Erfenis Dam where the species was first discovered. Although only known from three localities, this species is likely to be quite widespread in the Grassland Biome, and future pitfall studies aiming to collect this species should take into account the particular soil type apparently preferred by this species, as well as the restricted phenology of this species (male activity from the end of September to December). These considerations will allow for a much more accurate presentation of the distribution of the species and likelihood of success in sampling this species.

Long-necked or assassin spiders (Archaeidae) are a family of morphologically unique araneophagous spiders occurring in South Africa, Madagascar and Australia, with some species of Archaea recorded from Baltic amber (Wood, 2008). South African archaeids have typically been regarded as forest-dwelling specialists, primarily because most of the species were collected by leaf litter sifting in forests. Two of the South African species, Afrarchaea harveyi and A. royalensis, were described by $\operatorname{Lotz}(2003,2006)$ from the type localities only, i.e. Champagne Castle and Royal Natal National Park in KwaZulu-Natal, respectively. During recent field work in January 2011, additional records of A. harveyi were collected in open grassland at Champagne Castle and Cathedral Peak by searching at the base of grass tussocks, under rocks and under Berkheya leaves close to the ground, while additional records of $A$. royalensis were collected at Royal Natal in forest leaf litter and at Platberg Nature Reserve in the eastern Free State at the base of grass tussocks in open grassland $(\mathrm{H}$. Wood, pers. comm.). Therefore, the presumption that Afrarchaea only occur in forests is false; some of the species at least frequent moist grasslands where they can be readily collected 
once their preferred microhabitats have been identified. Thus, only by sampling particular microhabitats thoroughly can the resident spiders be identified, and hypotheses alternative to "popular thinking" be proposed regarding their broad habitat/biome preferences as well as specific microhabitat preferences.

\subsection{Forests - Islands of endemism?}

The Forest Biome in South Africa is composed of three vegetation types, namely Afromontane (Afrotemperate) forests, sand forest and coastal forest. Together, these vegetation types only cover approximately $0.3 \%$ of South Africa's land surface (Mucina \& Rutherford, 2006). To date 51 families represented by 223 genera and 508 species have been recorded from forests. The Thomisidae with 71 species are the most species rich, followed by the Salticidae (70) and Araneidae (43).

Afromontane forests are particularly under threat, with nearly $30 \%$ of this vegetation type transformed or degraded. In contrast, nearly half of the sand forest habitat is protected in formal conservation areas (Eeley et al., 2001). The South African Afromontane forests occur as small fragments within a fynbos, grassland or savanna matrix, and are predominantly found along the slopes of mountain ranges in the south, east and north-east of the country. Sand forest is very localised and only occurs on the Maputaland coastal plain of Northern KwaZulu-Natal, extending into southern Mozambique where it is known as Licuati forest. Coastal forest forms a relatively continuous belt from the Eastern Cape northwards, extending into East Africa. While the Forest Biome has been extensively sampled in South Africa, few quantitative published studies exist on the spider fauna (Van der Merwe \& Dippenaar-Schoeman, 1996; Dippenaar-Schoeman \& Wassenaar, 2002, 2006; Haddad et al., 2010).

Amongst invertebrates, high levels of diversity and endemism have been recorded for harvestmen (De Bivort \& Giribet, 2010), snails (Bursey \& Herbert, 2004; Herbert, 2006; Govender, 2007; Cole \& Herbert, 2009), millipedes (Hamer \& Slotow, 2002, 2009) and velvet worms (Daniels et al., 2009) in South African forests. While considerable speciation has taken place in the aforementioned groups, spiders have generally not followed suit to the same degree, with only 33 species being endemic to forest and 141 near endemics, although the origin of these forests biota is complex and ancient. Griswold (1991a) pointed to the inability of dispersal and Pleistocene vicariance to explain the biogeographical patterns of four Afromontane spider taxa, Microstigmata (Microstigmatidae), Moggridgea quercina group (Migidae) and the tribes Vidoleini and Phyxelidini (Phyxelididae), instead proposing Mesozoic origins for some of the observed patterns. A contemporary review of his findings could provide a test of this assertion, particularly since many of the species that were originally recorded from the Forest Biome are now widespread within forests and/or occupy habitats in several different biomes.

There are, however, several notable exceptions. For example, the six South African species of Microstigmata (Microstigmatidae) are considered to be restricted to forest habitats in the eastern half of the country (KwaZulu-Natal and Eastern Cape Provinces), with the exception of M. zuluense and M. longipes that also occasionally occur in savanna habitats in northern KwaZulu-Natal (Griswold, 1985, 1991b; Dippenaar-Schoeman et al., 2006). Using the endemism classes of Hamer \& Slotow (2002) and the published data of Griswold (1985), two species could be considered site endemics (only one locality), one species a local endemic (distribution range of $11-70 \mathrm{~km}$ ), and three species as South African endemics, with a distribution range of $>150 \mathrm{~km}$. As a result of collecting since Griswold's revision, including 
SANSA sampling, one of the site endemics (M. ukhahlamba) can now be considered a South African endemic, occurring widely in forest patches in the Drakensberg Mountains. The first specimens of $M$. longipes from Table Mountain in the Western Cape Province were also recorded, thereby disputing Griswold's (1985) proposal that the genus is absent from the western Cape Fold Mountains. This makes the absence of the genus from the more continuous Afromontane forests of the Outeniqua Mountains of the southern Eastern and Western Cape Provinces, where extensive leaf litter collecting in forests has been conducted, even more puzzling.

Griswold (1990) recognised 54 species in his global revision of the family Phyxelididae (then a subfamily of Amaurobiidae), of which 30 species are known from South Africa. Ten of these species $(33 \%)$ were suggested to be endemic to the Forest Biome or occur in closed canopy bush, while the other 20 species (67\%) are troglobitic or occur in grassland, savanna, fynbos or desert habitats, occasionally also occurring in forests (Griswold, 1990). Thus, at least a few of the species of most of the South African genera seem largely specialised to occur in forest habitats.

Within the family Zoropsidae, two endemic South African genera are presently recognised, namely Griswoldia (formerly Machadonia) and Phanotea (Griswold, 1991b, 1994). Both Griswold and Lawrence (1953) regarded these two genera as important components of the cryptic fauna of moist South African forests. Regarding Griswoldia, 11 of the 12 described species were recorded from Afromontane or coastal forests, with only G. urbense reported from grasslands also. The extensive sampling in South Africa following the generic revision indicates that only two of the species, G. meikleae and G. sibyna, are entirely restricted to forest; the remaining species in the genus have now also been recorded from fynbos, grassland, savanna or thicket habitats. Griswold (1994) also proposed that the 10 species of Phanotea were largely restricted to closed canopy forests, except for three species also found in fynbos and one ( $P$. peringueyi) known only from caves. Following SANSA, only one species, $P$. knysna, is known only from forests. The others have now also been recorded from fynbos, grassland, savanna and/or thicket habitats too. Despite the fact that zoropsids are not restricted to forests, most species can still be regarded as essential components of forest spider assemblages.

\subsection{Fynbos - Tantalizing correlates of diversity}

Fynbos covers only about $6.7 \%$ of South Africa (about $85000 \mathrm{~km}^{2}$ ) but has the largest number of plant species of any biome in the country (about 7500). Most fynbos is found along the coast and in the Cape Fold Mountains between Nieuwoudtville in the north-west and Port Elizabeth in the east (Fig. 2). The Fynbos Biome includes both fynbos and Renosterveld vegetation.

The Fynbos Biome of South Africa has been the focus of considerable attention due to the high levels of plant diversity and endemism. While this may be true for the field of Botany, the invertebrate fauna, and spiders in particular, has remained comparatively poorly studied. To date, only four studies have been published on the spider diversity of the biome (Coetzee et al., 1990; Visser et al., 1999; Haddad \& Dippenaar-Schoeman, 2009; Mukherjee et al., 2010). However, several studies are currently underway, including a long term survey that started in 2004 in the Cederberg Mountains, where invertebrates are sampled in 17 sites along an altitudinal gradient (Botes et al. 2006). Initial results points to the discovery of several new species along the transect (Seshothela \& Dippenaar-Schoeman, 2011). Presently 61 families represented by 251 genera and 636 species are known from the Fynbos Biome, 
with 189 species being endemics and 102 near endemics. The Salticidae with 240 spp. are the most diverse, followed by the Gnaphosidae (176) and Thomisidae (133).

Data from intensively sampled fynbos localities, such as the De Hoop Nature Reserve where 252 spider species were recorded (Haddad \& Dippenaar-Schoeman, 2009), indicate that the fauna is less diverse that the Savanna Biome, where species counts regularly exceed 275 species. However, family diversity is the highest so far recorded in South Africa, with 54 families recorded from the reserve. When one considers that fynbos is a structurally less complex vegetation type than savanna, this diversity is quite remarkable.

Perhaps most interesting is the high levels of endemism in the Fynbos Biome reported for some families. For the family Corinnidae, for example, 10 of the 15 species recorded from De Hoop Nature Reserve are fynbos endemics, of which several have only recently been described (Haddad, 2006; Haddad \& Lyle, 2008; Lyle \& Haddad, 2010; Lyle, 2011). The same was found in the Cederberg, where three of the four species of Ammoxenidae sampled are new fynbos endemics (Seshothela \& Dippenaar-Schoeman, 2011).

\subsection{Nama and Succulent Karoo}

The Nama Karoo Biome is the second-largest biome in South Africa and the distribution of this biome is determined primarily by rainfall that varies between 100 and $520 \mathrm{~mm}$ per year, with the dominant vegetation being grassy, dwarf shrubland. It is bordered to the west side by the Succulent Karoo Biome that covers a flat to gently undulating plain, with some hilly and "broken" veld, mostly situated to the west and south of the escarpment, and north of the Cape Fold Belt (Fig. 2). Rainfall in the Succulent Karoo Biome varies between 20 and 290 $\mathrm{mm}$ per year and the vegetation is dominated by dwarf, succulent shrubs that are particularly prominent. There is little difference between the soils of the Succulent Karoo and Nama Karoo Biomes - both are lime-rich, weakly developed soils on rock.

Presently 464 spp. from 50 families are known from the Nama Karoo, of which 74 are endemics and 77 near endemics. The Gnaphosidae are the most diverse with 76 spp., followed by the Salticidae (49) and Thomisidae (32). Only 44 families have been recorded from the Succulent Karoo Biome so far, represented by 117 genera and 219 spp., of which 49 are endemics and 40 near endemics. The families Gnaphosidae (34 spp.), Lycosidae (25 spp.) and Salticidae (13 spp.) are the most diverse. Both of these biomes remain the most neglected in terms of qualitative long-term sampling in South Africa, despite considerable effort to sample and understand the scorpion fauna of these biomes. Most sampling was done on an ad hoc basis between 1890-1930 by arachnologists stationed in the South African Museum, resulting in a fair number of species being described (e.g. Tucker, 1923). Published results are mainly from collecting undertaken in the Mountain Zebra National Park (Dippenaar-Schoeman, 1988), Karoo National Park (Dippenaar-Schoeman et al., 1999a), Swartberg Nature Reserve (Dippenaar-Schoeman et al., 2005b) and Nama Karoo grassland (Haddad \& Dippenaar-Schoeman, 2005).

Logistical constraints due to the distance that needs to be travelled by suitably qualified collectors from their bases, which are predominantly in the eastern half of the country, hampered new SANSA collections. The common perception is that these dry arid biomes have a low diversity of arachnids and are difficult to sample in, thus giving a low species yield per unit effort. This is clearly reflected in the number of sampling records from these biomes, and most notably, the presence of two degree-square grids from which no spiders have yet been recorded (Fig. 2). What needs to be appreciated is that while both reasons have some validity, the fauna that exists in these biomes is uniquely adapted to these arid 
habitats, and likely shows high levels of endemism. These biomes are thus of considerable interest biogeographically, phylogenetically and from a conservation perspective. Jenkins et al. (2011) also point to the importance of these arid areas in developing our understanding of the effects of global climate change.

Due to the low vegetation, fewer plant- and web-dwelling spiders are recorded, but a rich fauna of ground dwellers is present. There are a number of endemics found in ground dwelling families such as the Ammoxenidae (12 spp.) and several trapdoor spider families: Cyrtaucheniidae (8); Ctenizidae (13); Idiopidae (7) en Nemesiidae (11) (Dippenaar-Schoeman, 2002). More than 100 species of Gnaphosidae alone are known from these biomes, most of which were described by Tucker (1923) in his revision of the family in South Africa, with several endemics. Other ground dwelling spiders such as the genus Tyrotama (4 species) of the Hersiliidae (Foord \& Dippenaar-Schoeman, 2005) and ground-dwelling Eresidae (DippenaarSchoeman, 1989) have several species that are endemic to these arid biomes.

\subsection{Thicket, between a rock and a hard place}

The Thicket Biome is found from the west coast to KwaZulu-Natal, with most of the biome being found in the Eastern Cape. It makes up 2.5\% of the area of South Africa (nearly 31500 $\mathrm{km}^{2}$ ) and the vegetation ranges from shrubland to low forest. There are many evergreen and succulent trees and shrubs and many of the plants have spines or thorns. Analysis of the spider assemblages did, however, suggest that this biome overlaps considerably with other biome types, and could potentially be grouped together with the fauna of the Savanna Biome. No published surveys are known from this biome but several surveys are presently underway. To date 55 families represented by 206 genera and 464 spp. have been recorded from thicket, of which 90 are endemics and 96 near endemics. The Thomisidae with $62 \mathrm{spp}$. are the most diverse, followed by the Salticidae (38) and Araneidae (37).

\subsection{Agro-ecosystems}

South Africa has about $12 \%$ arable land and some of these areas were sampled to determine the spider diversity. Spiders are one of the most ubiquitous predator groups in agroecosystems (Van den Berg \& Dippenaar-Schoeman, 1991a) and inventories in South Africa have provided valuable baseline information on species in agroecosystems (Table 2). As predators, spiders have a two-fold function. Not only do they feed directly on their prey, but their presence also causes indirect mortality of arthropods. The presence of spiders could disturb larvae who then drop from the plant and die. The webs spun over the surface of leaves also seems to make them less suitable for oviposition and feeding. Therefore, while considerable effort has been put into baseline surveys in agroecosystems in South Africa, there is a large scope for further experimental work on the biological control potential of the dominant agobiont spiders in each agroecosystem.

The family Salticidae has been shown to be an important component of agrobiont assemblages. In a knock-down study of three macadamia orchards in the Mpumalanga Lowveld in South Africa, $73 \%$ of the sampled spiders were salticids (jumping spiders). Salticids were also the most diverse (17 species), of which four species represented more than $61 \%$ of all spiders collected. Thyene coccineovittata was the most abundant species and represented $30 \%$ of all the spiders collected, followed by $T$. natali with $14 \%$, Viciria alba with $9 \%$ and Tusitala guineensis with $8 \%$. These four species were present throughout the year in all three orchards sampled (Dippenaar-Schoeman et al., 2001a, b). 
Salticidae were also the dominant spider family in pistachio orchard canopies in the arid Northern Cape, although their abundance varied between the three orchards sampled: Green Valley Nuts 1 (81.2\%), Remhoogte (58.8\%) and Green Valley Nuts 19 (82.4\%). It seems that factors such as tree canopy size, presence or absence of bark and dry leaves, climatic conditions, and orchard size may be the main influences on spider abundance (Haddad et al., 2005). The fauna of ground covers was dominated by Salticidae in Green Valley Nuts 1 (37.2\%) and Remhoogte (35.0\%), while Oxyopidae dominated the ground cover fauna of the youngest orchard, Green Valley Nuts 19 (31.9\%) (Haddad et al., 2004a). Four families, Linyphiidae, Lycosidae, Salticidae and Gnaphosidae, dominated the ground-dwelling fauna of the orchards, although the abundance of each differed considerably between sampling methods (pitfall trapping and active searching) and also between orchards (Haddad \& Dippenaar-Schoeman, 2006b).

\begin{tabular}{|l|l|l|l|l|l|l|}
\hline Crop & Province & Methods & Family & Genus & spp. & References \\
\hline Citrus & $\begin{array}{l}\text { Eastern Cape, } \\
\text { Mpumalanga, } \\
\text { Limpopo, } \\
\text { North West }\end{array}$ & $\begin{array}{l}\text { Hand, } \\
\text { beating }\end{array}$ & 21 & 35 & 197 & $\begin{array}{l}\text { (Dippenaar-Schoeman, } \\
1998)\end{array}$ \\
\hline Cotton & $\begin{array}{l}\text { North West, } \\
\text { Mpumalanga, } \\
\text { Limpopo }\end{array}$ & $\begin{array}{l}\text { Whole- } \\
\text { bag; hand; } \\
\text { pittraps }\end{array}$ & 31 & 92 & 127 & $\begin{array}{l}\text { (Van den Berg et al., } \\
\text { Dippenaar-Schoeman, } \\
\text { 1991b; Dippenaar- } \\
\text { Schoeman et al., 1999b) }\end{array}$ \\
\hline Bt cotton & Limpopo & $\begin{array}{l}\text { Pittraps; } \\
\text { scouting }\end{array}$ & 21 & 49 & 54 & $\begin{array}{l}\text { (Mellet et al., 2006) } \\
\text { Avocado }\end{array}$ \\
Mpumalanga & Fogging & 26 & 68 & 90 & $\begin{array}{l}\text { (Dippenaar-Schoeman et } \\
\text { al., 2005a) }\end{array}$ \\
\hline Macadamia & Mpumalanga & Fogging & 21 & 57 & 80 & $\begin{array}{l}\text { (Dippenaar-Schoeman et } \\
\text { al., 2001a, b) }\end{array}$ \\
\hline Pistachio & $\begin{array}{l}\text { Northern } \\
\text { Cape }\end{array}$ & $\begin{array}{l}\text { Fogging; } \\
\text { sweeping; } \\
\text { hand; } \\
\text { pittraps }\end{array}$ & 31 & 83 & 143 & $\begin{array}{l}\text { (Haddad et al., 2004a; } \\
\text { Haddad et al., 2005; } \\
\text { Haddad \& Dippenaar- } \\
\text { Schoeman 2006b) }\end{array}$ \\
\hline Strawberries & Gauteng & Hand & 14 & 20 & 32 & $\begin{array}{l}\text { (Dippenaar-Schoeman, } \\
\text { 1979) }\end{array}$ \\
\hline
\end{tabular}

Table 2. Crops in South Africa that have been surveyed for spiders and for which agrobiont spider species have been identified.

Preliminary data of spider prey items included Thysanoptera (Phlaeothripidae), Coleoptera (Bruchidae, Coccinellidae, Chrysomelidae), Diptera (Tephritidae, Muscidae, Cecidomyiidae), Acari (Tetranychidae), and various Lepidoptera larvae. Laboratory and field experiments on Heliophanus pistaciae (Salticidae), the dominant arboreal agrobiont species, indicated that it has potential as a biological control agent of the false cinch bug, Nisius natalensis (Hemiptera: Lygaeidae), one of the minor pests of pistachio nuts in South Africa (Haddad et al., 2004b). 


\subsection{Public education, participation and awareness (SANSA)}

This constitutes another important component of the CBD and SANSA, aimed to increase awareness about arachnids to wider society through a variety of activities that includes an extensive website $^{3}$ containing information on the activities of SANSA. Additional information is also available on: 1) all the arachnid orders; 2) survey results; 3) medically important spiders; 4) arachnid research; 5) virtual museum entries; and 6) copies of newsletters and reports.

Target audiences are also identified and information is disseminated in the appropriate communication medium and language through books, CD's, posters, magazine and newspaper articles, pamphlets, TV and radio (Dippenaar-Schoeman \& Jocqué, 1997; Dippenaar-Schoeman, 2002; Dippenaar-Schoeman \& Van den Berg, 2010; Holm \& Dippenaar-Schoeman, 2010). In addition to several radio and television appearances by Dippenaar-Schoeman, the Spider Educare Programme based at the National Collection of Arachnida has conducted road shows to schools, lectures to societies and clubs, and courses presented at Universities for the past ten years.

The online Virtual Museum of South African Arachnids presently houses about 3400 images received from 80 photographers throughout the country. Not only is it a wonderful display of photographs, but it also provides valuable information on species' behaviour, colour patterns and prey. Colour patterns in particular are lost when the spiders are killed and preserved in alcohol. The Virtual Museum has provided the spider images for two full colour books that have recently been published (Dippenaar-Schoeman \& Van den Berg, 2010; Holm \& Dippenaar-Schoeman, 2010).

\section{Conclusion}

Resources for surveys will always be limited and funding will have to be directed at answering targeted questions. Three biomes that require particular attention are the Thicket, Nama and Succulent Karoo Biomes. The Fynbos is also of particular significance as it seems to match the better known savanna biome in terms of spider diversity based on preliminary survey results. The hypothesized restricted distributions of species to Afromontane forests have also been rejected because of contemporary discoveries of these taxa in other biomes employing techniques that target specific microhabitats.

Two taxa, the families Theridiidae and Lycosidae, comprise the bulk of what constitutes a taxonomic impediment to a better understanding of diversity patterns in spiders. The family Salticidae is another important family, dominant in all ecosystems, that fortunately has and will continue to receive considerable taxonomic attention. The potential of this family as a surrogate of spider diversity, in conjunction with families such as Thomisidae and Gnaphosidae, could be explored, should the taxonomic impediment of taxa mentioned earlier persist.

We view the future research as a combination of optimized and standardized inventories in the degree squares of the four biomes identified. This will provide both cost efficient and comparable results. These inventories will, however, have to include protocols that target cryptic biotopes. The by-catch of other invertebrate taxa also provides the opportunity to collaborate with specialists on these taxonomic groups generating data on a "shopping basket" of taxa, as has been shown by a study that was done using the ant by-catch of one of the SANSA surveys (Schoeman \& Foord, In press). These inventories have to be

${ }^{3}$ www.arc.agric.za quick link SANSA 
complemented by targeted studies at regional and local scales over larger temporal scales if we are to fully understand the dynamics of spider assemblages in South Africa.

\section{Acknowledgments}

The authors would like to thank the Agricultural Research Council (ARC) and the South African National Biodiversity Institute (SANBI) for funding SANSA. Several volunteers and taxonomic specialists contributed to both SANSA and the National Collection of Arachnida, and their enthusiasm and assistance greatly contributed to the success of the project. We would also like to thank the data management team at the ARC.

\section{References}

Botes, A, McGeoch, MA, Robertson, HG, Van Niekerk, A, Davids, HP, Chown, SL. (2006). Ants, altitude and change in the northern Cape Floristic Region. J Biogeogr 33: 71-90.

Bursey, ML, Herbert, DG. (2004). Four new narrow-range endemic species of Gulella from Eastern Cape, South Africa (Mollusca: Pulmonata: Streptaxidae). Afr Invert 45: 249262.

Butler, VP, Haddad, CR. (in press). Spider communities associated with leaf litter of three tree species in central South Africa (Arachnida: Araneae). Afr J Ecol.

Cardoso, P, Scharff, N, Gaspar, CS, Henriques, SS, Carvalho, R, Castro, PH, Schmidt, JB, Silva, I, Szuts, T, De Castro, A, Crespo, LC. (2008). Rapid biodiversity assessment of spiders (Araneae) using semi-quantitative sampling: a case study in a Mediterranean forest. Insect Cons Divers 1: 71-84.

Chao, A, Chazdon, RL, Colwell, RK, Shen, T-J. (2005). A new statistical approach for assessing compositional similarity based on incidence and abundance data. Ecol Lett 8: 148-159.

Coddington, JA, Agnarsson, I, Miller, JA, Kuntner, M, Hormiga, G. (2009). Undersampling bias: the null hypothesis for singleton species in tropical arthropod surveys. J Anim Ecol 78: 573-584.

Coetzee, JH, Dippenaar-Schoeman, AS, Van den Berg, A. (1990). Spider assemblages on five species of proteaceous plants in the fynbos biome of South Africa. Phytophylatica 22: 443-447.

Cole, ML, Herbert, DG. (2009). Decription of four new species of Gulella Pfeiffer, 1856 from Eastern Cape, South Africa, with additional notes on two poorly known species (Mollusca, Eupulmonata: Streptaxidae). Zool Meded (Leiden) 83: 547-564.

Daniels, SR, Picker, MD, Cowlin, RM, Hamer, ML. (2009). Unraveling evolutionary lineages among South African velvet worms (Onychophora: Peripatopsis) provides evidence for widespread cryptic speciation. Biol J Linn Soc 97: 200-216.

De Bivort, BL, Giribet, G. (2010). A systematic revision of South African Petallidae (Arachnida: Opiliones: Cyphophthalmi) based on a combined analysis of discrete and continuous characters with the description of seven new species. Invertebr Syst 24: 371-406.

Dippenaar-Schoeman, AS. (1979). Spider communities in strawberry beds: seasonal changes in numbers and species composition. Phytophylatica 11: 1-4.

Dippenaar-Schoeman, AS. (1988). Annotated check list of the spiders (Araneae) of the Mountain Zebra National Park. Koedoe 31: 151-160. 
Dippenaar-Schoeman, AS. (1989). The African species of the sub family Penestominae (Araneae: Eresidae): with description of two new species. Phytophylatica 21: 131-134.

Dippenaar-Schoeman, AS. (1998) Spiders as predators of citrus pests. Agricultural Research Council, Nelspruit.

Dippenaar-Schoeman, AS. (2002) Baboon and Trapdoor Spiders of Southern Africa: An Identification Manual. Agricultural Research Council, Pretoria.

Dippenaar-Schoeman, AS. (2007). South African National Survey of Arachnida: assessment and consolidation of data. Newsl South African Nat Survey Arachnida 3: 7-15.

Dippenaar-Schoeman, AS, Craemer, C. (2000). The South African National Survey of Arachnida. Plant Prot News 56: 11-12.

Dippenaar-Schoeman, AS, Jocqué, R. (1997) African spiders: An identification manual. Agricultural Research Council, Pretoria.

Dippenaar-Schoeman, AS, Leroy, A. (2003). A checklist of the spiders of the Kruger National Park, South Africa (Arachnida: Araneae). Koedoe 46: 91-100.

Dippenaar-Schoeman, AS, Leroy, A, De Jager, M, Van den Berg, A. (1999a). Spider diversity of the Karoo National Park, South Africa. Koedoe 41: 31-42.

Dippenaar-Schoeman, AS, Van den Berg, A, Prendini, L. (2009). Spiders and Scorpions (Arachnida: Araneae, Scorpiones) of the Nylsvley Nature Reserve, South Africa. Koedoe 51: 1-9.

Dippenaar-Schoeman, AS, Van den Berg, AM. (2010) Spiders of the Kalahari. Agricultural Research Council, Pretoria.

Dippenaar-Schoeman, AS, Van den Berg, AM, Van den Berg, A. (1989). Species composition and relative seasonal abundance of spiders from the field and tree layers of the Roodeplaat Dam Nature Reserve. Koedoe 32: 51-60.

Dippenaar-Schoeman, AS, Van den Berg, AM, Van den Berg, MA. (1999b). Spiders in South African cotton fields: species diversity and abundance (Arachnida: Araneae). Afr Plant Prot 5: 93-103.

Dippenaar-Schoeman, AS, Van den Berg, AM, Van den Berg, MA, Foord, SH. (2005a). Spiders in avocado orchards in the Mpumalanga Lowveld of South Africa: species diversity and abundance (Arachnida: Araneae). Afr Plant Prot 11: 8-16.

Dippenaar-Schoeman, AS, Van den Berg, MA, Van den Berg, A. (2001a). Salticid spiders in macadamia orchards in the Mpumalanga Lowveld of South Africa (Arachnida: Araneae). Afr Plant Prot 7: 47-51.

Dippenaar-Schoeman, AS, Van den Berg, MA, Van den Berg, A. (2001b). Spiders in macadamia orchards in the Mpumalanga Lowveld of South Africa: species diversity and abundance (Arachnida: Araneae). Afr Plant Prot 7: 39-46

Dippenaar-Schoeman, AS, Van der Merwe, M, Van den Berg, AM. (2006). Habitat preferences and seasonal activity of the Microstigmatidae from Ngome State Forest, South Africa (Arachnida: Araneae). Koedoe 49: 85-89.

Dippenaar-Schoeman, AS, Van der Walt, AE, De Jager, M, Le Roux, E, Van den Berg, A. (2005b). The spiders of the Swartberg Nature Reserve in South Africa (Arachnida: Araneae). Koedoe 49: 23-28.

Dippenaar-Schoeman, AS, Wassenaar, TD. (2002). A checklist of the ground-dwelling spiders of coastal dune forests at Richards Bay, South Africa (Arachnida: Araneae). Bull Br Arachnol Soc 12: 275-279. 
Dippenaar-Schoeman, AS, Wassenaar, TD. (2006). A checklist of spiders from the herbaceous layer of a coastal dune forest ecosystem at Richards Bay, KwaZuluNatal, South Africa (Arachnida: Araneae). Afr Invert 47: 63-70.

Dippenaar, SM, Dippenaar-Schoeman, AS, Modiba, MA, Khoza, TT (2008). A checklist of spiders (Arachnida, Araneae) of the Polokwane Nature Reserve, Limpopo Province, South Africa. Koedoe 50: 10-17.

Eeley, HC, Lawes, MJ, Reyers, B. (2001). Priority areas for the conservation of subtropical indigenous forest in southern Africa: a case study from KwaZulu-Natal. Biodivers Conserv 10: 1221-1246.

Engelbrecht, I. (2010). Invertebrate species inventories in protected area management: are they useful? Afr Entomol 18: 235-245.

Foord, SH, Dippenaar-Schoeman, AS. (2005). A revision of the Afrotropical species of Hersiliola Thorell and Tama Simon with the description of a new genus Tyrotama (Araneae: Hersiliidae). Afr Entomol 13: 255-279.

Foord, SH, Dippenaar-Schoeman, AS. (2006). A revision of the Afrotropical species of Hersilia Audouin (Araneae: Hersiliidae). Zootaxa: 5-92.

Foord, SH, Dippenaar-Schoeman, AS, Van der Merwe, M. (2002). A check list of the spider fauna of the Western Soutpansberg, South Africa (Arachnida: Araneae). Koedoe 45: $35-43$.

Foord, SH, Mafadza, M, Dippenaar-Schoeman, AS, Van Rensburg, BJ. (2008). Micro-scale heterogeneity of spiders (Arachnida: Araneae) in the Soutpansberg, South Africa: a comparative survey and inventory in representative habitats. Afr Zool 43: 156-174.

Fourie, R, Haddad, CR, Jocqué, R. (2011). A revision of the purse web spider genus Calommata Lucas, 1837 (Araneae: Atypidae) in the Afrotropical Region. Zookeys 95: 1-28.

Govender, V, 2007. Patterns of distribution, diversity and endemism of terrestrial molluscs in South Africa. Unpublished M.Sc thesis, University of KwaZulu-Natal, Pietermaritzburg.

Griswold, CE. (1985). A revision of the African spiders of the family Microstigmatidae (Araneae: Mygalomorphae). Ann Nat Mus 27: 1-37.

Griswold, CE. (1990). A revision and phylogenetic analysis of the spider subfamily Phyxelidinae (Araneae, Amaurobiidae). Bull Am Mus Nat Hist 196: 1-206.

Griswold, CE. (1991a). Cladistic biogeography of Afromontane spiders. Aust Syst Biol 43: 7389.

Griswold, CE. (1991b). A revision and phylogenetic analysis of the spider genus Machadonia Lehtinen (Araneae, Lycosoidea). Entomol Scand 22: 305-351.

Griswold, CE. (1994). A revision and phylogenetic analysis of the spider genus Phanotea Simon (Araneae, Lycosoidea). Ann Musee Roy Afr Centr, Sci Zool 273: 1-83.

Haddad, CR. (2006). Spinotrachelas, a new genus of trachelinae sac spiders from South Africa (Araneae: Corinnidae). Afr Invert 47: 85-93.

Haddad, CR. (2010). A new species of Poachelas from Maputaland, South Africa (Araneae: Corinnidae), with considerable range extension for Poachelas striatus. Afr Invert 51: 313-319.

Haddad, CR, Dippenaar-Schoeman, AS. (2002). The influence of mound structure on the diversity of spiders (Araneae) inhabiting the abandoned mounds of the snouted harvester termite Trinervitermes trinervoides. J Arachnol 30: 403-408. 
Haddad, CR, Dippenaar-Schoeman, AS. (2005). Epigaeic spiders (Arachnida: Araneae) in Nama Karoo grassland in the Northern Cape Province. Navors Nas Mus Bloemfontein 21: 1-10.

Haddad, CR, Dippenaar-Schoeman, AS. (2006a). Spiders (Araneae) inhabiting abandoned mounds of the snouted harvester termite Trinervitermes trinervoides (Sjöstedt) (Isoptera: Termitidae: Nasutitermitinae) in the Free State, South Africa. Navors Nas Mus Bloemfontein 22: 1-15.

Haddad, CR, Dippenaar-Schoeman, AS. (2006b). Epigaeic spiders (Araneae) in pistachio orchards in South Africa. Afr Plant Prot 12: 12-22.

Haddad, CR, Dippenaar-Schoeman, AS. (2009). A checklist of the non-acarine arachnids (Chelicerata: Arachnida) of the De Hoop Nature Reserve, Western Cape Province, South Africa. Koedoe 51: 1-9.

Haddad, CR, Dippenaar-Schoeman, AS, Wesołowska, W. (2006). A checklist of the nonacarine arachnids (Chelicerata: Arachnida) of the Ndumo Game Reserve, Maputaland, South Africa. Koedoe 49: 1-22.

Haddad, CR, Honiball, AS, Dippenaar-Schoeman, AS, Slotow, R. (2010). Spiders as potential indicators of elephant-induced habitat changes in endemic sand forest, Maputaland, South Africa. Afr J Ecol 48: 446-460.

Haddad, CR, Louw, SVDM, Dippenaar-Schoeman, AS. (2004a). Spiders (Araneae) in ground covers of pistachio orchards in South Africa. Afr Plant Prot 10: 97-107.

Haddad, CR, Louw, SVDM, Dippenaar-Schoeman, AS. (2004b). An assessment of the biological control potential of Heliophanus pistaciae (Araneae: Salticidae) on Nysius natalensis (Hemiptera: Lygaeidae), a pest of pistachio nuts. Biol Control 31: 83-90.

Haddad, CR, Lyle, R. (2008). Three new genera of tracheline sac spiders from southern Africa (Araneae: Corinnidae). Afr Invert 49: 37-76.

Hamer, ML, Slotow, RH. (2002). Conservation implications of existing data for South African millipedes (Diplopoda). Afr Entomol 10: 29-42.

Hamer, ML, Slotow, RH. (2009). A comparison and conservation assessment of the high altitude grassland and forest millipede (Diplopoda) fauna of the South African Drakensberg. Soil Org 81: 701-717.

Herbert, DG. (2006). Rediscovery of the type species of Euonyma (Sabulinidae) and observations on South African species of Gulella (Streptaxidae), with description of two new species (Gastropoda: Eupulmonata). J Nat Hist 40: 1063-1081.

Holm, E, Dippenaar-Schoeman, AS. (2010) Goggo Guide: The Arthropods of Southern Africa. LAPA Publishers, Pretoria.

Jenkins, CN, Sanders, NJ, Andersen, AN, Arnan, X, Brühl, CA, Cerda, X, Ellison, AM, Fisher, BL, Fitzpatrick, MC, Gotelli, NJ, Gove, AD, Guénard, B, Lattke, JE, Lessard, J-P, McGlynn, TP, Menke, SB, Parr, CL, Philpott, SM, Vasconcelos, HL, Weiser, MD, Dunn, RR. (2011). Global diversity in light of climate change: the case of ants. Divers Distrib 17: 652-662.

Jocqué, R. (2001). Chummidae, a new spider family (Arachnida, Araneae) from South Africa. J Zoology (Lond) 54: 481-493.

Jocqué, R. (2008). A new candidate for a Gondwanaland distribution in Zodariidae (Araneae): Australutica in Africa. Zookeys 1: 59-66.

Johnson, BL. (1999). The role of adaptive management as an operational approach for resource management agencies. Conserv Ecol 3: 8. 
Lawrence, RF. (1953) The Biology of the Cryptic Fauna of Forests with Special Reference to Indigenous Forests of South Africa. Balkema Publishing Cape Town, Cape Town.

Lomolino, MV, Riddle, BR, Brown, JH. (2006) Biogeography, 3rd edn. Sinauer Associates, Inc., Sunderland, USA.

Lotz, LN. (2003). Afrotropical Archaeidae: 2. New species of the genera Archaea and Afrarchaea (Arachnida: Araneae). Navors Nas Mus Bloemfontein 19: 221-240.

Lotz, LN. (2006). Afrotropical Archaeidae: 3. The female of Eriauchenius cornutus and new species of Afrarchaea (Arachnida: Araneae) from South Africa. Navors Nas Mus Bloemfontein 22: 113-126.

Lotz, LN, Seaman, MT, Kok, DJ. (1991). Surface-active spiders (Araneae) of a site in semiarid central South Africa. Navors Nas Mus Bloemfontein 7: 529-540.

Lyle, R. (2011). The male of Fuchiba tortilis Haddad and Lyle, 2008 and three new species of Spinotrachelas Haddad, 2006 (Araneae: Corinnidae: Trachelinae) from South Africa. Ann Ditsong Nat Mus Nat Hist 1: 123-131

Lyle, R, Haddad, CR. (2010). A revison of the tracheline sac spider genus Cetonana Strand, 1929 in the Afrotropical Region, with descriptions of two new genera (Araneae: Corinnidae). Afr Invert 51: 321-384.

Makaka, L, Little, IT, Dippenaar-Schoeman, AS, Jansen, R. (In review). Montane grassland management and the implications on ground living spider community structure in South Africa (Arachnida, Araneae). Agric Ecosyst Environ.

Mellet, MA, Schoeman, AS, Dippenaar-Schoeman, AS. (2006). The effect of Bt-cotton cultivation on spider populations in Marble Hall, South Africa. Afr Plant Prot 12: 4050.

Miller, JA, Griswold, CE, Haddad, CR. (2010). Taxonomic revision of the spider family Penestomidae (Araneae, Entelegynae). Zootaxa 2534: 1-36.

Modiba, MA, Dippenaar, SM, Dippenaar-Schoeman, AS. (2005). A check list of spiders from Sovenga Hill an inselberg in the Savanna Biome, Limpopo Province, South Africa (Arachnida: Araneae). Koedoe 48: 109-115.

Mucina, L, Rutherford, MC. (2006) The vegetation of South Africa, Lesotho and Swaziland. Strelitzia 19, South African National Biodiversity Institute, Pretoria.

Muelelwa, MI, Foord, SH, Dippenaar-Schoeman, AS, Stam, EM. (2010). Towards a standardized and optimized protocol for rapid assessments: spider species richness and assemblage composition in two savanna vegetation types. Afr Zool 45: 273-290.

Mukherjee, A, Wilske, B, Navarro, RA, Dippenaar-Schoeman, AS, Underhill, LG. (2010). Association of spiders and lichens on Robben Island, South Africa: a case report. J Threat Taxa 2: 815-819.

Platnick, NI. (1991). Patterns of biodiversity: tropical vs temperate. J Nat Hist 25: 1083-1088.

Pullin, AS. (2002) Conservation Biology. Cambridge University Press, Cambridge.

Schoeman, CS, Foord, SH. (In press). A checklist of epigaeic ants from Marakele National Park, Limpopo Province, South Africa (Hymenoptera: Formicidae). Koedoe.

Seshothela, SL, Dippenaar-Schoeman, AS. (2011). Termite eating spiders of the Cederberg Wilderness Area (Araneae: Ammoxenidae). Abstracts of the 10 th African Arachnological Colloquium: 28.

Van den Berg, A, Dippenaar-Schoeman, AS. (1991a). Ground-living spiders from an area where the harvester termite Hodotermes mossambicus occurs in South Africa. Phytophylatica 23: 247-253. 
Van den Berg, AM, Dippenaar-Schoeman, AS. (1991b). Spiders, predacious insects and mites on South African cotton. Phytophylatica 23: 85-86.

Van den Berg, AM, Dippenaar-Schoeman, AS, Schoonbee, HJ. (1990). The effect of two pesticides on spiders in Southern African cotton fields. Phytophylatica 22: 435-441.

Van der Merwe, M, Dippenaar-Schoeman, AS. (1996). Diversity of ground-living spiders at Ngome State Forest, KwaZulu-Natal: a comparative survey in indigenous forest and pine plantations. Afr J Ecol 48: 342-350.

Visser, D, Wright, MG, Van den Berg, A, Giliomee, JH. (1999). Species richness of arachnids associated with Protea nitida (Proteaceae) in the Cape Fynbos. Afr J Ecol 37: 334-343.

Wesołowska, W, Haddad, CR. (2009). Jumping spiders (Araneae: Salticidae) of the Ndumo Game Reserve, Maputaland, South Africa. Afr Invert 50: 13-103.

Whitmore, C, Slotow, R, Crouch, TE, Dippenaar-Schoeman, AS. (2002). Diversity of spiders (Araneae) in a Savanna reserve, Northern Province, South Africa. J Arachnol 30: 344356.

Wood, H. (2008). A revision of the assassin spiders of the Eriauchenius gracilicollis group, a clade of spiders endemic to Madagascar (Araneae: Archaeidae). Zool J Linn Soc 152: 255-296. 


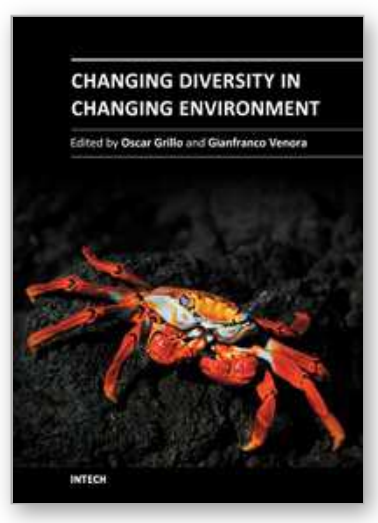

\author{
Changing Diversity in Changing Environment \\ Edited by PhD. Oscar Grillo
}

ISBN 978-953-307-796-3

Hard cover, 392 pages

Publisher InTech

Published online 14, November, 2011

Published in print edition November, 2011

As everybody knows, the dynamic interactions between biotic and abiotic factors, as well as the anthropic ones, considerably affect global climate changes and consequently biology, ecology and distribution of life forms of our planet. These important natural events affect all ecosystems, causing important changes on biodiversity. Systematic and phylogenetic studies, biogeographic distribution analysis and evaluations of diversity richness are focal topics of this book written by international experts, some even considering economical effects and future perspectives on the managing and conservation plans.

\title{
How to reference
}

In order to correctly reference this scholarly work, feel free to copy and paste the following:

Stefan H. Foord, Anna S. Dippenaar-Schoeman and Charles R. Haddad (2011). South African Spider Diversity: African Perspectives on the Conservation of a Mega-Diverse Group, Changing Diversity in Changing Environment, PhD. Oscar Grillo (Ed.), ISBN: 978-953-307-796-3, InTech, Available from:

http://www.intechopen.com/books/changing-diversity-in-changing-environment/south-african-spider-diversityafrican-perspectives-on-the-conservation-of-a-mega-diverse-group

\section{INTECH}

open science | open minds

\section{InTech Europe}

University Campus STeP Ri

Slavka Krautzeka 83/A

51000 Rijeka, Croatia

Phone: +385 (51) 770447

Fax: +385 (51) 686166

www.intechopen.com

\section{InTech China}

Unit 405, Office Block, Hotel Equatorial Shanghai

No.65, Yan An Road (West), Shanghai, 200040, China

中国上海市延安西路65号上海国际贵都大饭店办公楼405单元

Phone: +86-21-62489820

Fax: +86-21-62489821 
(C) 2011 The Author(s). Licensee IntechOpen. This is an open access article distributed under the terms of the Creative Commons Attribution 3.0 License, which permits unrestricted use, distribution, and reproduction in any medium, provided the original work is properly cited. 